\title{
EFFECT OF SUBSTITUTED MERCAPTOPURINES ON THE RAT LITTER IN UTERO
}

\author{
J. B. THIERSGH \\ Department of Pharmacology, University of Washington, Seattle, U.S.A.
}

(Received 19th February 1962)

\begin{abstract}
Summary. 6-Amyl, 6-propyl, and 6-benzyl, 2-amino-6-benzyl and 6- $\left(2^{\prime} 4^{\prime}\right.$ dinitrophenyl)-mercaptopurine (MP) were examined for the effect on the rat litter in utero. The toxicity of the $\mathbf{L D}_{50}$ for the mother rat varied from 300 to more than $500 \mathrm{mg} / \mathrm{kg}$. Complete litter destruction with the compounds was possible on the 7 th day of gestation with doses tolerated by the mothers. The best ratios between $\mathrm{LD}_{50}$ to the mother and the lethal dose to the litter of $1: 12$ were obtained with $6-\left(2^{\prime} 4^{\prime}\right.$ dinitrophenyl) and of $1: 10$ with 2-amino-6-benzyl-MP. This was followed by 6-propyl and 6-benzyl-mp with a ratio of $1: 5$, followed by 6-amylMP with a ratio of $1: 2 \cdot 5$. The findings indicate that none of the compounds achieved as favourable a ratio between $L D_{50}$ to the mother and litter destruction as 6-thioguanine with $1: 30$.
\end{abstract}

\section{INTRODUCTION}

In previous work, (Thiersch, 1954, 1957), it was established that 6-mercaptopurine, 6-chloropurine and especially 6-thioguanine would destroy the foetuses and litters of the rat in utero with doses well tolerated by the mothers. In the present study, an attempt was made to detect other substituted thiopurines which might have a better ratio between the $\mathrm{LD}_{50}$ to the mother animal and the lethal dose to the litter.

\section{MATERIALS AND METHOD}

The compounds, supplied by G. Hitchings with toxicity data, are listed in Table 1. The materials are less toxic than 6-mercaptopurine and are in the range of toxicity of 6-chloropurine or 6-thioguanine. The materials were dissolved in distilled water and given orally or intraperitoneally. The LongEvans strain of rats was used entirely in the present experiments. The procedure followed was previously outlined in the 6-mercaptopurine paper (Thiersch, 1954). The onset of pregnancy was determined in the animals by the finding of masses of spermatozoa or a solid plug in the vagina. The animals were then separated into single stainless steel cages where urinary and faecal contact was impossible. The mother rats were then injected at different periods of their gestation and sacrificed on the 21st day of gestation under ether anaesthesia. The uteri were then removed, the uterine contents noted and recorded, the 
surviving placentas and foetuses measured and weighed. The skeletons of surviving foetuses were cleared with oil of wintergreen to study possible malformation and stained with alizarin. The results of the experiments were tabulated and are seen in Table 1. Malformations were not induced in any surviving foetuses.

TABLE 1

EFFECT OF SUBSTITUTED MERGAPTOPURINES ON THE RAT LITTER in utero

\begin{tabular}{|c|c|c|c|c|c|}
\hline Compound & $\begin{array}{l}\text { Single LD } 50 \\
\text { (mg/kg i.p.) }\end{array}$ & $\begin{array}{l}\text { Complete litter } \\
\text { destruction } 7 \text { th } \\
\text { gestation day } \\
(m g / k g \text { dose })\end{array}$ & $\left|\begin{array}{c}\text { Ratio } \\
\text { LD50 to } \\
\text { mothers } \\
\text { Lethal } \\
\text { litter dose }\end{array}\right|$ & $\begin{array}{c}\text { Dose 11th } \\
\text { gestation day } \\
\text { (mg/kg) }\end{array}$ & $\begin{array}{l}\text { Resorbed } \\
\text { foetuses } \\
(\%)\end{array}$ \\
\hline $\begin{array}{l}\text { 6-Chloropurine } \\
\text { 6-Thioguanine } \\
\text { 6-Mercaptopurine } \\
\text { 6-Amyl-MP } \\
\text { 6-Propyl-MP } \\
\text { 6-Benzyl-MP } \\
\text { 2-Amino-6-benzyl-MP } \\
\text { 6-(2'4' Dinitrophenyl)-MP } \\
\text { 6-1'-Methyl, 4'-nitro, } \\
\text { 5'-imidazolyl-MP } \\
\text { 2-Amino-6-1'-methyl, } \\
\text { 4'-nitro, 5'-imidazolyl- } \\
\text { MP }\end{array}$ & 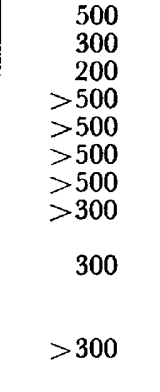 & $\begin{array}{r}100 \\
10 \\
30 \\
200 \\
100 \\
75 \\
100 \\
50 \\
10\end{array}$ & $\begin{array}{l}1: 5 \\
1: 30 \\
1: 6 \\
1: 2 \cdot 5 \\
1: 5 \\
1: 5 \\
1: 10 \\
1: 12 \\
1: 30 \\
1: 40\end{array}$ & \begin{tabular}{|c|c} 
& 100 \\
10 \\
30 \\
200 \\
150 \\
50 \\
50 \\
100 \\
\\
20 \\
\\
\\
20 \\
oral 50
\end{tabular} & $\begin{array}{r}14 \\
75 \\
5 \\
20 \\
6 \\
7 \\
\overline{7} \\
2\end{array}$ \\
\hline
\end{tabular}

Summary of results of substituted mercaptopurines tested for effect on rat litter in utero. 6-Chloropurine, 6-thioguanine (Thiersch, 1954) and 6-MP (Thiersch, 1957) are compared with heterocyclic substituted MP. Note maximal effect on litter immediately after implantation ( $7 \mathrm{th}$ day of gestation) and insensitivity at mid-term (11 th day of gestation).

TABLE 2

6-AMYL-MP. LD50 GREATER THAN 500 MG/KG I.P.

\begin{tabular}{|c|c|c|c|c|c|c|c|c|c|}
\hline \multirow[b]{3}{*}{$\begin{array}{c}\text { Dose } \\
(\mathrm{mg} / \mathrm{kg} \\
\text { i.p. }\end{array}$} & \multirow[b]{3}{*}{$\begin{array}{c}\text { Day of dose } \\
\text { (post coitum) }\end{array}$} & \multirow[b]{3}{*}{ No. rats } & \multirow[b]{3}{*}{$\begin{array}{c}\text { Total } \\
\text { implantations }\end{array}$} & \multicolumn{5}{|c|}{ Foetuses } & \multirow[b]{3}{*}{$\begin{array}{l}\text { Mothers with } \\
\text { entire litter } \\
\text { resorbed }(\%)\end{array}$} \\
\hline & & & & \multicolumn{5}{|c|}{ Total implantations (\%) } & \\
\hline & & & & Normal & Stunted & Dead & $\begin{array}{c}\text { Completely } \\
\text { resorbed }\end{array}$ & $\begin{array}{c}\text { Surviving } \\
\text { placentas } \\
\text { only }\end{array}$ & \\
\hline $\begin{array}{r}50 \\
50 \\
100 \\
200 \\
200\end{array}$ & $\begin{array}{c}7+8 \\
11+12 \\
7 \\
7 \\
11\end{array}$ & $\begin{array}{r}10 \\
17 \\
13 \\
11 \\
9\end{array}$ & $\begin{array}{r}111 \\
186 \\
142 \\
126 \\
88\end{array}$ & $\begin{array}{r}66 \\
99 \\
15 \\
0 \\
67\end{array}$ & $\begin{array}{l}0 \\
0 \\
5 \\
0 \\
7\end{array}$ & $\begin{array}{l}2 \\
0 \\
0 \\
0 \\
0\end{array}$ & $\begin{array}{r}22 \\
0 \\
53 \\
100 \\
16\end{array}$ & $\begin{array}{r}10 \\
1 \\
27 \\
0 \\
10\end{array}$ & $\begin{array}{c}20 \\
0 \\
61 \cdot 5 \\
100 \\
11 \cdot 1\end{array}$ \\
\hline
\end{tabular}

6-Amyl-MP

\section{RESULTS}

$\mathrm{LD}_{50}$ greater than $500 \mathrm{mg} / \mathrm{kg}$ intraperitoneally (i.p.) (Table 2). The table shows that a single $100-\mathrm{mg}$ dose given on the 7 th day of gestation reduced the number of surviving foetuses to $20 \%$ and destroyed completely eight out of thirteen litters in the group of rats tested. The $200-\mathrm{mg} / \mathrm{kg}$ dose did not permit survival 
of a single foetus. From Table 2, it is evident that the ratio between the $\mathrm{LD}_{50}$ to the mother and the lethal dose to the litter is approximately $1: 2.5$.

\section{6-Propyl-мP}

Single $\mathrm{LD}_{50}$ greater than $500 \mathrm{mg} / \mathrm{kg}$ i.p. (Table 3). In doses of $50 \mathrm{mg} / \mathrm{kg}$ i.p.

\section{TABLE 3}

6-PROPYL-MP. LD50 GREATER THAN 500 MG/KG I.P.

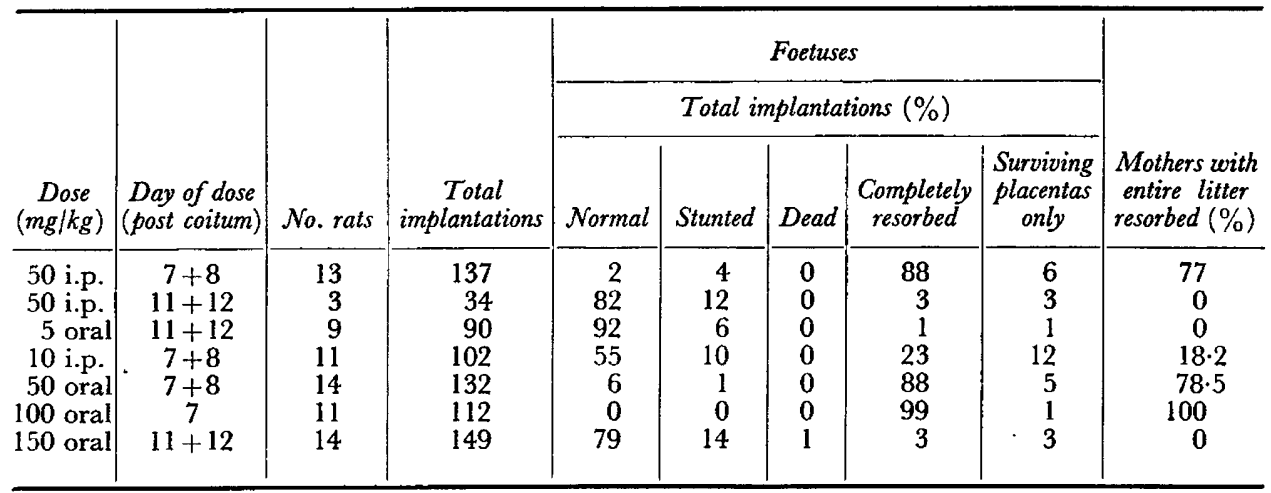

given on the 7th and 8th day of gestation, this compound permitted only the survival of $6 \%$ of the foetuses and completely destroyed ten out of thirteen litters. Most of the surviving foetuses were stunted. The same dose given i.p. or even $150 \mathrm{mg} / \mathrm{kg}$ orally on the 11 th and 12 th day of gestation was not effective, permitting the survival of $94 \%$ of all foetuses. The $50-\mathrm{mg} / \mathrm{kg}$ oral doses given on the 7 th and 8 th day had the same results as the i.p. doses. The $100-\mathrm{mg}$ doses given orally on the 7 th day destroyed all litters and foetuses. From Table 3 , it is evident that the $\mathrm{LD}_{50}$ to the mother and the litter-destroying doses was approximately $1: 5$.

TABLE 4

6-BENZYL-MP. LD50 GREATER THAN $500 \mathrm{MG/KG} \mathrm{I.P.}$

\begin{tabular}{|c|c|c|c|c|c|c|c|c|c|}
\hline \multirow[b]{3}{*}{$\begin{array}{c}\text { Dose } \\
(\mathrm{mg} / \mathrm{kg})\end{array}$} & \multirow[b]{3}{*}{$\begin{array}{c}\text { Day of dose } \\
\text { (post coitum) }\end{array}$} & \multirow[b]{3}{*}{ No. rats } & \multirow[b]{3}{*}{$\begin{array}{c}\text { Total } \\
\text { implantations }\end{array}$} & \multicolumn{5}{|c|}{ Foetuses } & \multirow[b]{3}{*}{$\begin{array}{l}\text { Mothers with } \\
\text { entire litter } \\
\text { resorbed }(\%)\end{array}$} \\
\hline & & & & \multicolumn{5}{|c|}{ Total implantations (\%) } & \\
\hline & & & & Normal & Stunted & Dead & $\begin{array}{c}\text { Completely } \\
\text { resorbed }\end{array}$ & $\begin{array}{c}\text { Surviving } \\
\text { placentas } \\
\text { only }\end{array}$ & \\
\hline $\begin{array}{c}50 \text { i.p. } \\
50 \text { i.p. } \\
50 \text { i.p. } \\
100 \text { oral } \\
50 \text { i.p. }\end{array}$ & $\begin{array}{r}5 \\
7 \\
11 \\
7 \\
6\end{array}$ & $\begin{array}{r}9 \\
13 \\
11 \\
13 \\
5\end{array}$ & $\begin{array}{r}83 \\
128 \\
101 \\
136 \\
49\end{array}$ & $\begin{array}{r}83 \\
20 \\
88 \\
0 \\
86\end{array}$ & $\begin{array}{l}0 \\
0 \\
0 \\
0 \\
0\end{array}$ & $\begin{array}{l}0 \\
0 \\
5 \\
0 \\
0\end{array}$ & $\begin{array}{r}15 \\
68 \\
0 \\
95 \\
7\end{array}$ & $\begin{array}{r}2 \\
12 \\
7 \\
5 \\
7\end{array}$ & $\begin{array}{r}0 \\
77 \\
0 \\
100 \\
0\end{array}$ \\
\hline
\end{tabular}

6-Benzyl-мP

Single $\mathrm{LD}_{50}$ greater than $500 \mathrm{mg} / \mathrm{kg}$ i.p. (Table 4). In doses of $50 \mathrm{mg} / \mathrm{kg}$ i.p. given on the 7th day the compound permitted the survival of $20 \%$ of all the foetuses and completely destroyed ten out of thirteen litters. The same dosage given on the 11 th day of gestation i.p. had only a minor effect on the foetuses. A 
100-mg oral dose given on the 7th day of gestation destroyed all foetuses and litters. This gives a ratio of $L D_{50}$ to the mother and lethal dose to the litter of approximately $1: 5$.

\section{2-Amino-6-benzyl-MP}

Single $\mathrm{LD}_{50}$ greater than $500 \mathrm{mg} / \mathrm{kg}$ (Table 5). A $100-\mathrm{mg}$ oral dose given on

TABLE 5

2-AMINO, 6-BENZYL-MP. LD50 MORE THAN 500 MG/KG I.P.

\begin{tabular}{|c|c|c|c|c|c|c|c|c|c|}
\hline \multirow[b]{3}{*}{$\begin{array}{c}\text { Dose } \\
(m g / k g)\end{array}$} & \multirow[b]{3}{*}{$\begin{array}{c}\text { Day of dose } \\
\text { (post coitum) }\end{array}$} & \multirow[b]{3}{*}{ No. rats } & \multirow[b]{3}{*}{$\begin{array}{c}\text { Total } \\
\text { implantations }\end{array}$} & \multicolumn{5}{|c|}{ Foetuses } & \multirow[b]{3}{*}{$\begin{array}{l}\text { Mothers with } \\
\text { entire litter } \\
\text { resorbed }(\%)\end{array}$} \\
\hline & & & & \multicolumn{5}{|c|}{ Total implantations (\%) } & \\
\hline & & & & Normal & Stunted & Dead & $\begin{array}{c}\text { Completely } \\
\text { resorbed }\end{array}$ & $\begin{array}{l}\text { Surviving } \\
\text { placentas } \\
\text { only }\end{array}$ & \\
\hline $\begin{array}{l}20 \text { i.p. } \\
20 \text { i.p. } \\
50 \text { i.p. } \\
50 \text { i.p. } \\
50 \text { i.p. } \\
50 \text { i.p. } \\
50 \text { i.p. } \\
100 \text { oral }\end{array}$ & $\begin{array}{r}5 \\
7 \\
5 \\
7 \\
9 \\
10 \\
11 \\
7\end{array}$ & $\begin{array}{r}10 \\
11 \\
13 \\
18 \\
9 \\
10 \\
10 \\
12\end{array}$ & $\begin{array}{r}84 \\
100 \\
135 \\
192 \\
93 \\
105 \\
103 \\
112\end{array}$ & $\begin{array}{c}80 \\
22 \\
84 \\
0 \cdot 6 \\
89 \\
95 \\
100 \\
5 \cdot 5\end{array}$ & $\begin{array}{l}1 \\
7 \\
3 \\
0 \\
0 \\
0 \\
0 \\
0\end{array}$ & $\begin{array}{l}0 \\
0 \\
0 \\
0 \\
0 \\
0 \\
0 \\
0\end{array}$ & $\begin{array}{c}14 \\
59 \\
7 \\
93 \cdot 4 \\
2 \\
3 \\
0 \\
84 \cdot 5\end{array}$ & $\begin{array}{r}5 \\
12 \\
6 \\
6 \\
9 \\
2 \\
0 \\
10\end{array}$ & $\begin{array}{c}10 \\
45 \cdot 5 \\
0 \\
89 \\
0 \\
0 \\
0 \\
83 \cdot 3\end{array}$ \\
\hline
\end{tabular}

TABLE 6

6-(2'4' DINITROPHENYL)-MP. LD50 GREATER THAN 300 MG/KG I.P.

\begin{tabular}{|c|c|c|c|c|c|c|c|c|c|}
\hline \multirow[b]{3}{*}{$\begin{array}{c}\text { Dose } \\
(m g / k g \\
i . p .)\end{array}$} & \multirow[b]{3}{*}{$\begin{array}{c}\text { Day of dose } \\
\text { (post coitum) }\end{array}$} & \multirow[b]{3}{*}{ No. rats } & \multirow[b]{3}{*}{$\begin{array}{c}\text { Total } \\
\text { implantations }\end{array}$} & \multicolumn{5}{|c|}{ Foetuses } & \multirow[b]{3}{*}{$\begin{array}{l}\text { Mothers with } \\
\text { entire litter } \\
\text { resorbed }(\%)\end{array}$} \\
\hline & & & & \multicolumn{5}{|c|}{ Total implantations (\%) } & \\
\hline & & & & Normal & Stunted & Dead & $\begin{array}{c}\text { Completely } \\
\text { resorbed }\end{array}$ & $\begin{array}{c}\text { Surviving } \\
\text { placentas } \\
\text { only }\end{array}$ & \\
\hline 50 & $7+8$ & 12 & 140 & 0 & 0 & 0 & 100 & 0 & 100 \\
\hline 10 & 11 & 10 & 110 & 93 & 1 & 0 & 5 & 1 & 0 \\
\hline 10 & 7 & 13 & 147 & 61 & 10 & 0 & 19 & 10 & 77 \\
\hline 2. & $7+8$ & 15 & 141 & 96.5 & 2 & 0 & 0 & 1.5 & 0 \\
\hline 25 & 7 & 14 & 138 & 0 & 0 & 0 & 93 & 7 & 100 \\
\hline 50 & 7 & 13 & 155 & 0 & 0 & 0 & 94 & 6 & 100 \\
\hline 50 & 11 & 10 & 89 & 100 & 0 & 0 & 0 & 0 & 0 \\
\hline 100 & 11 & 12 & 119 & 83 & 20 & 2 & 3 & 2 & 0 \\
\hline
\end{tabular}

the 7 th day of gestation destroyed $94 \%$ of all foetuses and ten out of twelve litters completely. The $20-\mathrm{mg} / \mathrm{kg}$ i.p. dose given on the 7 th day of gestation destroyed $71 \%$ of all foetuses and stunted seven of the survivors. However, only five of eleven litters were entirely destroyed. The 50-mg-i.p. dose given on the 7th day of gestation to a group of eighteen rats permitted the survival of less than $1 \%$ of all the foetuses and completely destroyed sixteen out of eighteen litters.

From this, it is evident that amination in the 2 position on the molecule increased the effect on the foetuses. The data shows a ratio of $1: 10$ between the $\mathrm{LD}_{50}$ to the mother and complete litter destruction.

\section{6-(2'4' Dinitrophenyl)-MP}

Single $\mathrm{LD}_{50}$ greater than $300 \mathrm{mg} / \mathrm{kg}$ i.p. (Table 6). A single $25-\mathrm{mg} / \mathrm{kg}$ dose 
given i.p. on the 7 th day of gestation destroyed all litters and foetuses. In contrast to this, the $100-\mathrm{mg} / \mathrm{kg}$ i.p. dose given on the 11 th day had hardly any effect on the life of the foetuses, but stunted $20 \%$. This gave a ratio of $\mathrm{LD}_{50}$ to the mother and lethal dose to the litter of $1: 12$.

\section{DISCUSSION}

From the findings listed in the Tables, it is evident that the most efficient compound in litter destruction was the $6-\left(2^{\prime} 4^{\prime}\right.$ dinitrophenyl $)$-MP followed by the 2-amino-6-MP. It is evident that the effect of the compounds was most marked on the 7th day of gestation as soon as implantation was completed. Neither before or later in foetal life were similar results obtained. On the 1Ith day of gestation, even multiple doses, sufficient to destroy the entire litters in groups of animals on the 7th day of gestation, had only minor effects on the litter in utero. This confirms previous observations with 6-mercaptopurine, 6-chloropurine and 6-thioguanine.

Histological examinations of the spleen, liver, kidney, adrenals and bone marrow of the mother animals showed no evidence of bone-marrow depression or lesions that could be histologically called significant. The bone-marrow depression which followed injection of the animals had subsided and the bone marrow had completely recovered at the time of sacrifice.

\section{ACKNOWLEDGMENTS}

This work was carried out with a Grant-in-Aid by the Population Council and the U.S.P.H. Service.

The generous supply with the compounds by $\mathrm{Dr}$ G. Hitchings from Burroughs Wellcome Research Institute is gratefully acknowledged.

\section{REFERENCES}

ThIersch, J. B. (1954) The effect of 6-mercaptopurine on the rat fetus and on reproduction of the rat. Ann. N.Y. Acad. Sci. 60, 220.

ThIERsch, J. B. (1957) Effect of 2-6 diaminopurine (2-6 DP): 6 chloropurine (CIP) and 6 thioguanine (ThG) on rat litter in utero. Proc. Soc. exp. Biol., N.Y. 87, 571. 